\title{
PERLINDUNGAN HUKUM TERHADAP NASABAH ATAS PENYELENGGARAAN LAYANAN PERBANKAN DIGITAL
}

\author{
Herdian Ayu Andreana Beru Tarigan1, Darminto Hartono Paulus² \\ IFakultas Hukum, Universitas Muhammadiyah Surakarta \\ 2Fakultas Hukum, Universitas Diponegoro \\ herdian_ay96@yahoo.com
}

\begin{abstract}
Increasing competition in the Indonesian banking industry has encouraged many banks to improve the quality of services to customers by utilizing the development of information technology. Service innovation in the use of information technology encourages banks to enter the era of digital banking services. However, the development of digital banking services also increases the risks faced by banks. The purpose of this study is to provide an overview of the implementation of digital banking services and customer protection for risks from digital banking services. The method used in this study is an empirical legal research method. The results of this study indicate that the implementation of digital banking services is regulated by 0J K Regulation No.12 I P0J K.03 / 2018 which is a preventive protection related to customer protection. The existence of this 0J K Regulation is expected by banks as providers of digital banking services to always prioritize risk management in the use of information technology. Repressive protection in the form of bank accountability for complaints from customers who use digital banking services.
\end{abstract}

Keywords: Customer Protection; Digital Banking Services; Bank.

\begin{abstract}
ABSTRAK
Semakin tingginya persaingan di industri perbankan Indonesia, mendorong banyak bank meningkatkan kualitas pelayanan kepada nasabah dengan memamfaatkan perkembangan teknologi informasi. Inovasi layanan dalam penggunanan teknologi informasi mendorong perbankan untuk memasuki era layanan perbankan digital. Namun, berkembangnya layanan perbankan digital juga meningkatkan resiko yang akan dihadapi oleh bank. Tujuan dari penelitian ini adalah untuk memberikan gambaran penyelenggaraan layanan perbankan digital serta perlindungan nasabah atas resiko dari layanan perbankan digital. Metode yang digunakan penelitian ini adalah metode penelitian hukum yuridis empiris. Hasil dari penelitian ini menunjukan bahwa penyelenggaraan layanan perbankan digital diatur oleh Peraturan OJK No.12/POJK.03/2018 yang merupakan perlindungan preventif terkait perlindungan nasabah. Adanya Peraturan OJK ini diharapkan bank sebagai penyelenggara layanan perbankan digital selalu mengedepankan menejemen risiko dalam penggunaan teknologi informasi. Perlindungan represif berupa pertanggungjawaban pihak bank atas pengaduan dari nasabah pengguna layanan perbankan digital.
\end{abstract}

Kata Kunci: Perlindungan Nasabah; Layanan Perbankan Digital; Bank.

\footnotetext{
${ }^{*}$ Corresponding Author
} 
Jurnal Pembangunan Hukum Indonesia

Volume 1, Nomor 3, Tahun 2019
Program Studi Magister Ilmu Hukum Fakultas Hukum Universitas Diponegoro

\section{A. PENDAHULUAN}

Sekitar tahun 2000 SM di Kota Asyur dan Sumeria sudah terlihat adanya aktifitas perbankan dimana terjadi kegiatan perdagangan yang memberikan pinjaman biji-bijian kepada para petani dan pedagang yang membawa barang-barang antar kota. Aktifitas tersebut terus berkembang sehinggga melahirkan industri perbankan saat ini termasuk di Indonesia (Kholis, 2018).

Perbankan merupakan lembaga intermediasi keuangan yang bertugas mengumpulkan dana dari masyarakat. Bank merupakan lembaga kepercayaan untuk menyimpan uangnya dan mempercayakan bank dalam mengelola keuangannya. Dalam menjalankan operasionalnya bank dibedakan atas dua yaitu bank konvensional dan bank syariah (bank yang menjalankan operasionalnya berdasarkan prinsip syariah). Pertumbuhan perbankan saat ini sangat signifikan dapat dilihat dari banyaknya bank diseluruh wilayah Indonesia (Vebiana, 2018) dalam Industrial Research Workshop and National Seminar.

Perbankan sebagai industri jasa keuangan di Indonesia, merupakan industri yang memegang peranan penting dalam kegiatan perekonomian (Cvijovic, Stankovic, \& Relljic, 2017). Perbankan juga memiliki peranan dalam upaya peningkatan kesejahteraan rakyat dengan menunjang pelaksanaan pembangunan nasional (Chosyali \& Sartono, 2019). Banyaknya variasi layanan yang ditawarkan oleh bank yang berbeda menyebabkan tingkat persaingan menjadi tinggi, khususnya untuk memperoleh nasabah. Disisi lain, perkembangan zaman juga menunjukan perubahan pola prilaku masyarakat dalam menggunakan layanan yang disediakan oleh perbankan, hal ini dikarenakan adanya perkembangan Teknologi Informasi. Fenomena tersebut mendorong perbankan menyediakan layanan keuangan berbasis Teknologi Informasi (financial technology) yang menawarkan inovasi barudalam layanan keuangan bank. Bagi perbankan, digitalisasi bukanlah sebuah pilihan tetapi menjadi keharusan dan kewajiban. Adanya harapan nasabah terkait kecepatan, kemudahan, fleksibilitas, kenyamanan dan tersedianya layanan bank $7 \times 24$ jam, mengharuskan beberapa perbankan di Indonesia melakukan transformasi layanan berbasis digital (Marlina, \& Bimo, 2018).

Perbankan yang melakukan peningkatan Teknologi Informasi dalam layanan kepada nasabah secara tidak langsung mengarahkan bank kepada suatu era baru yaitu era perbankan digital (Mbama, \& Catejan, 2018). Layanan kepada nasabah secara digital tersebut dapat diwujudkan sejak hubungan usaha antara nasabah dengan bank dimulai dari pembukaan rekening, eksekusi transaksi keuangan, hingga penutupan rekening simpanan yang dilakukan dengan memamfaatkan Teknologi Informasi (Marlina, \& Bimo, 2018). Beberapa permasalahan timbul akibat adanya layanan perbankan digital seperti kejahatan cybercrime yang kini semakin marak dan semakin tingginya perkembangan teknik penyalahgunaan data oleh pihak yang tidak bertanggungjawab. Cybercrime sudah menjadi kejahatan nomor satu bagi dunia perbankan terlebih di era digital seperti sekarang. 
Jurnal Pembangunan Hukum Indonesia

Volume 1, Nomor 3, Tahun 2019
Program Studi Magister Ilmu Hukum Fakultas Hukum Universitas Diponegoro
Pemanfaatan perkembangan teknologi informasi secara lebih optimal merupakan syarat dalam mendukung inovasi layanan bank. Inovasi layanan dan penyelenggaraan strategi dalam penggunanan teknologi informasi mendorong perbankan untuk memasuki era layanan perbankan digital. Layanan ini bertujuan meningkatkan efisiensi kegiatan operasional dan mutu pelayanan bank kepada nasabahnya. Untuk itu, bank perlu mengembangkan strategi bisnis yang mengarah pada layanan perbankan digital.

Peraturan OJK No.12/POJK.03/2018 Tentang Penyelenggaraan Layanan Perbankan Digital Oleh Bank Umum, menyebutkan "layanan perbankan digital adalah layanan perbankan elektronik yang dikembangkan dengan mengoptimalkan pemanfaatan data nasabah dalam rangka melayani nasabah secara lebih cepat, mudah dan sesuai dengan kebutuhan (customer experience) serta dapat dilakukan secara mandiri sepenuhnya oleh nasabah, dengan memperhatikan aspek pengamanan". Hal ini memungkinkan calon nasabah dan/atau nasabah Bank untuk memperoleh informasi, melakukan komunikasi, registrasi, pembukaan rekening, transaksi perbankan, dan penutupan rekening, termasuk memperoleh informasi lain dan transaksi di luar produk perbankan, antara lain nasihat keuangan (financial advisory), investasi, transaksi sistem perdagangan berbasis elektronik (ecommerce), dan kebutuhan lainnya dari nasabah Bank.
Pengembangan strategi bisnis yang mengarah kepada layanan perbankan digital memerlukan infrastruktur yang memadai. Di antaranya manajemen risiko, penyesuaian teknologi informasi, business model, business process, internal control, dan sumber daya manusia, untuk mendukung kenyamanan, keamanan, serta keandalan layanan perbankan digital dalam penyediaan informasi, komunikasi, registrasi, pembukaan rekening, pemrosesan transaksi, dan penutupan rekening.

Dengan mempertimbangkan kesiapan bank, maka penerapan layanan perbankan digital di Indonesia diawali dengan penyelenggaraan "digital branch", yaitu adanya sarana bank yang berfungsi secara khusus untuk memroses registrasi nasabah dan pembukaan rekening secara mandiri.

Seiring dengan perkembangan teknologi, digital bangking selalu mewarnai setiap aktifitas keuangan nasabah. Layanan perbankan digital (digital bangking) diharapkan dapat memberikan kemudahan pada level yang lebih tinggi dibandingkan dengan layanan yang sudah ada. Kemudahan yang diberikan membuat nasabah merasa diuntungkan, namun disisi lain, layanan tersebut juga akan meningkatkan resiko yang diahadapi oleh bank, terutama terkai resiko operasinal dan resiko reputasi jika terdapat masalahmasalah mengenai digital bangking tersebut (Kholis, 2018).

Dari hasil wawancara dengan Ibu Daramarisa Dwi Permata, CS Kantor BRI Unit Pasar Boyolali menyebutkan permasalahan yang sering dialami oleh 
Jurnal Pembangunan Hukum Indonesia

Volume 1, Nomor 3, Tahun 2019
Program Studi Magister Ilmu Hukum Fakultas Hukum Universitas Diponegoro nasabah terkait penggunaan layanan perbankan digital adalah masalah prosedural penggunaan internet bangking, membuat rekening secara mandiri melalui BRI mobile dan juga melalui Automated Teller Machine (ATM).

Berdasarkan uraian yang dikemukakan diatas, dapat dirumuskan permasalahan, yang perlu dikaji, yaitu bagaimana penyelenggaraan layanan perbankan digital di Indonesia?; dan bagaimana perlindungan hukum terhadap nasabah atas penyelenggaraan layanan perbankan digital ?

Tujuan penelitian ini merupakan cerminan terhadap masalah yang muncul dalam penulisan diatas, maka tujuan yang ingin dicapai adalah: pertama untuk mengetahui penyelenggaraan layanan perbankan digital di Indonesia; dan yang kedua, untuk mengetahui bagaimana perlindungan nasabah penggunan layanan perbankan digital.

Penelitian sebelumnya yang terkait dengan penelitian saat ini adalah Nur Kholis dengan fokus penelitian terhadap perbankan yang memanfaatkan perkembangan era digital (Kholis, 2018). Asti Marlina \& Widhi Ariyo Bimo dengan fokus penelitian terhadap peningkatan pelayanan melalui peningkatan digitalisasi bank untuk menghasilkan kepuasan nasabah bank (Marlina, \& Bimo, 2018). Talumewo dengan fokus penelitian terhadap pertanggungjawaban pihak bank sebagai upaya perlindungan nasabah terhadap kejahatan terkait ITE (Talumewo, 2013). Jelena Cvijovic, Milica Kostic Stankovic dan Marija Relijic dengan fokus penelitian terhadap manajemen pelayanan nasabah dalam industri perbankan (Cvijovic, Stankovic, \& Relljic, 2017). Serta Mbama \& Catejan dengan fokus penelitian ini terhadap pengalaman nasabah dalam penerapan teknologi perbankan digital di Inggris (Mbama, \& Catejan, 2018).

Walapun penelitian saat ini dan penelitian sebelumnya sama-sama terkait perkembangan pelayanan perbankan ke era digital namun fokus penelitian saat ini adalah perlindungan nasabah penggunaan layanan perbankan digital. Mengingat belum adanya penelitian tentang perlindungan nasabah pengguna layanan perbankan digital membuat pembahasan mengenai perlindungan nasabah pengguna layanan perbankan digital menjadi hal yang selalu penting dan aktual untuk dilakukan pengkajian.

\section{B. METODE PENELITIAN}

Metode adalah suatu cara yang harus dilalui dalam melakukan penelitian. Metode ini bertujuan untuk mengarahkan dan mencari serta menemukan kebenaran ilmiah yang sifatnya teroerinci dan dapat dipertanggungjwabkan secara ilmiah dan tidak menyimpang dari perumusan masalah. Pada penelitain ini, metode penelitian yang digunakan adalah yuridis empiris. Jenis data yang digunakan adalah data primer dan data sekunder. Data primer adalah data yang bersal dari responden yang terkait secara langsung dalam masalah. Sedangkan data sekunder berupa data yang diperoleh dari studi kepustakaan berupa bahan-bahan hukum seperti peraturan perundang-undangan, buku dan jurnal 
Jurnal Pembangunan Hukum Indonesia

Volume 1, Nomor 3, Tahun 2019
Program Studi Magister Ilmu Hukum Fakultas Hukum Universitas Diponegoro
(Salim, \& Nurbani, 2014). Dalam penelitian yuridis empiris ini, data primer yang didapatkan adalah data hasil wawancara penulis dengan narasumber yang bekerja sebagai Customer Service (CS) di PT. BRI Kantor Unit Pasar Boyolali. Pendekatan empiris dalam penelitian ini dilakukan dengan tujuan untuk memperoleh pengetahuan empiris sehingga memudahkan penulis dalam menyimpulkan (Chosyali, \& Sartono, 2019).

\section{HASIL DAN PEMBAHASAN}

1. Penyelenggaraan Layanan Perbankan Digital Menurut Peraturan 0J K No.12/POJ K.03/2018

Semakin tingginya persaingan di industri perbankan Indonesia, mendorong banyak bank meningkatkan kualitas pelayanan kepada nasabah dengan lebih efektif dan efisien. Mendorong efektifitas dan efisiensi pelayanan kepada nasabah, bank perlu semakin meningkatkan kapabilitas diikuti dengan penyelarasan strategi bisnis yang lebih tepat sasaran (Dendhana,2013). Maka dari itu, dalam upaya meningkatkan kapabilitas bank, pemanfaatan perkembangan teknologi informasi secara lebih optimal merupakan syarat dalam mendukung inovasi layanan bank. Inovasi layanan dan penyelenggaraan strategi dalam penggunanan teknologi informasi mendorong perbankan untuk memasuki era layanan perbankan digital (Ikatan Bankir Indonesia, 2014)

Peraturan OJK No.12/POJK.03/2018 Tentang Penyelenggaraan Layanan Perbankan Digital Oleh Bank Umum, menyebutkan "layanan perbankan digital adalah layanan perbankan elektronik yang dikembangkan

dengan

mengoptimalkan

pemanfaatan data nasabah dalam rangka melayani nasabah secara lebih cepat, mudah dan sesuai dengan kebutuhan (customer experience) serta dapat dilakukan secara mandiri sepenuhnya oleh nasabah, dengan memperhatikan aspek pengamanan".

Hasil wawancara dengan Ibu Daramarisa Dwi Permata, CS Kantor BRI Unit Pasar Boyolali menyebutkan contoh layanan perbankan digital yang berkembang saat ini adalah layanan pembukaan rekening secara mandiri oleh nasabah melalui Automated Teller Machine (ATM) yang sudah dikembangkan atau melalui aplikasi bank yang terdapat pada smartphone dan didukung dengan fasilitas pemindai sidik jari, pemindai kartu identitas dan video banking.

Ibu Daramarisa Dwi Permata, menambahkan bahwa contoh lain dari layanan perbankan digital termasuk layanan kredit perumahan kepada nasabah. Dalam memberikan persetujuan kredit, bank menganalisis data keuangan nasabah berupa posisi keuangan dan pola transaksi nasabah. Pengajuan kredit oleh nasabah dilakukan secara langsung melalui aplikasi bank yang terdapat pada smartphone nasabah dengan otorisasi transaksi antara lain menggunakan sidik jari.

Peraturan OJK No.12/POJK.03/2018 menyebutkan bank yang dapat melakukan penyelenggaraan layanan perbankan digital adalah bank umum yang disebutkan dalam UU No.10 Tahun 1998 Tentang Perbankan dan bank umum syariah 
Jurnal Pembangunan Hukum Indonesia

Volume 1, Nomor 3, Tahun 2019
Program Studi Magister Ilmu Hukum Fakultas Hukum Universitas Diponegoro sebagaimana dimaksud dalam UU No. 21 Tahun 2008 Tentang Perbankan Syariah. UU Perbankan dan UU Perbankan Syariah menyebutkan "bank adalah badan usaha yang menghimpun dana dari masyarakat dalam bentuk simpanan dan menyalurkannya kepada masyarakat dalam bentuk kredit dan atau bentuk-bentuk lainnya dalam rangka pengkatan taraf hidup rakyat banyak", sedangkan yang membedakan bank syariah dan bank kovensional pada umumnya adalah pelaksanaan usaha bank syariah yang berdasarkan prinsip syariah.

Penyelenggaraan layanan perbankan elektronik oleh bank dapat memamfaatkan saluran distribusi (delivery channel) (Palilati, 2016). Penjelasan Peraturan OJK No.12/POJK.03/2018 menyebutkan contoh saluran distribusi layanan perbankan elektronik antara lain "ATM (Automated Teller Machine), CDM (Cash Deposit Machibe), phone banking, Short Message Services (SMS) banking, Electronik Data Capture (EDC), Point of Sales (POS), internet banking dan mobile banking". Layanan perbankan digital adalah layanan atau kegiatan perbankan dengan menggunakan sarana elektronik atau digital milik Bank, dan/atau melalui media digital milik calon nasabah dan/atau nasabah Bank, yang dilakukan secara mandiri. Hal ini memungkinkan calon nasabah dan/atau nasabah Bank untuk memperoleh informasi, melakukan komunikasi, registrasi, pembuatan rekening, transaksi perbankan, dan penutupan rekening termasuk memperoleh informasi lain dan transaksi di luar produk perbankan, antara lain nasihat keuangan, investasi, transaksi sistem perdagangan berbasis elektronik, dan kebutuhan lainnya dari nasabah. (Otoritas Jasa Keuangan, 2019). Penyelenggaraan layanan perbankan digital sebagai produk lanjutan dari layanan perbankan elektronik yang dilakukan oleh bank harus memenuhi persyaratan, yaitu: 1). Memiliki peringkat profit resiko dengan peringkat 1 atau peringkat 2 berdasarkan penilaian tingkat kesehatan bank periode penilaian terakhir; 2). Memiliki infrastruktur teknologi informasi dan menajemen pengelolaan infrastruktur teknologi informasi yang memadai; dan 3).Termasuk dalam kelompok bank umum berdasarkan kegiatan usaha yang paling sedikit dapat melakukan kegiatan usaha layanan perbankan elektronik sebagaimana dalam ketentuan OJK. Persyaratan tersebut disebutkan dalam Pasal18 Peraturan OJK No.12/POJK.03/2018.

Layanan perbankan digital berdasarkan Peraturan OJK No.12/POJK.03/2018 dapat disediakan oleh bank dan/atau bank berdasarkan perjanjian kemitraan anatara bank dengan mitra bank berupa Lembaga Jasa Keuangan (LJK) atau lembaga non-LJK. Maksud dari layanan yang disediakan oleh bank adalah layanan perbankan digital yang diselenggarakan oleh bank. Penyelenggaraan teknologi informasi terkait layanan perbankan digital oleh bank dapat dilakukan secara mandiri dan/atau pihak penyedia jasa teknologi informasi. Sedangkan yang dimaksud dengan disediakan oleh bank berdasarkan perjanjian kemitraan antara bank dengan mitra bank adalah 
Jurnal Pembangunan Hukum Indonesia

Volume 1, Nomor 3, Tahun 2019
Program Studi Magister Ilmu Hukum Fakultas Hukum Universitas Diponegoro layanan perbankan digital yang diselenggarakan oleh bank bekerja sama dengan mitra bank.

Layanan digital banking mulai menjadi primadona di negara-negara maju Asia. Dengan potensi yang begitu besar, beberapa Bank mulai membuat layanan digital Banking di Asia. Bank asal Singapura DBS merilis produk Digibank di India pada tahun 2016, layanan mobile only digital banking tersebut juga masuk ke Indonesia pada tahun 2017. Ada juga layanan perbankan digital di korea Selatan yaitu kakaobank yang menjadi layanan perbankan digital dengan pertumbuhan paling signifikan dengan pengguna sebanyak 5,5 juta orang. (Sudarman, 2019). Dalam hal penyelenggaraan layanan perbankan digital yang disediakan oleh bank, bank wajib membentuk unit atau fungsi yang bertugas menangani penyelenggaraan layanan perbankan digital. Tugas dari unit atau fungsi tersebut adalah: a).Menyusun kebijakan, standard dan prosedur penyelenggaraan layanan perbankan digital; b).Memastikan kesesuain antara penyelenggaraan layanan perbankan digital dengan rencana strategis kegiatan usaha bank; c).Memantau pelaksanaan kerja sama dengan mitra bank dalam dalam penyelenggaraan layanan perbankan digital; d).Memantau data transaksi keuangan layanan perbankan digital; e).Memastikan efektifitas langkah yang digunanakan dalam menyelenggarakan layanan perbankan digital; f).Memantau kendala dan permasalahan yang muncul dari penyelenggaraan layanan perbankan digital; dan g).Memastikan kecukupan dan alokasi sumber daya terkait layanan perbankan digital yang dimiliki bank.

Layanan perbankan digital yang disediakan oleh bank kepada nasabah berupa layanan administrasi rekening, otorisasi transaksi (memamfaatkan data dan/atau informasi yang dapat dipertanggungjawabkan), pengelolaan keuangan, dan/atau pelayanan produk keuangan lain berdasarkan persetujuan OJK (Sutedi, 2014).

Hasil wawancara dengan Ibu Daramarisa Dwi Permata, CS Kantor BRI Unit Pasar Boyolali, menyampaikan layanan administrasi rekening meliputi pembukaan rekenig, pengkinian data nasabah hingga penutupan rekening dengan memamfaatkan media elektronik seperti aplikasi bank pada smartphone, yang dilengkapi dengan fasilitas pemindai sidik jari, pemindai kartu identitas dan kamera. Sedangkan contoh untuk layanan otorisasi transaksi seperti aplikasi mobile banking yang sudah dikembangkan membaca suara nasabah sehingga nasabah dapat membuka atau masuk pada aplikasi mobile banking dengan memindai suara. Selain pemindai suara, nasabah yang memiliki smartphone dilengkapi dang aplikasi pendukung penggunaan QR code atau Near Field Comunication (NFC) dapat melakukan transaksi pembayan pada merchant yang bekerja sma dengan bank. Nasabah dapat memindai QR code atau NFC dalam smartphone pada mesin pembaca untuk pendebetan secara otomatis sesuai dengan nominal transaksi.

Bank dalam melakukan hubungan usaha dengan nasabah melalui layanan perbankan digital 
Jurnal Pembangunan Hukum Indonesia

Volume 1, Nomor 3, Tahun 2019
Program Studi Magister Ilmu Hukum Fakultas Hukum Universitas Diponegoro wajib melakukan identifikasi nasabah atau calon nasabah kemudian melakukan verifikasi atas informasi dan dokumen pendukung nasabah dan calon nasabah. Verifikasi informasi dan dokumen pendukung nasabah atau calon nasabah dapat dilakukan oleh bank melalui tatap muka dan tanpa tatap muka. Melalui tatap muka dapat dilakukan secara langsung (face to face) atau menggunakan perangkat lunak milik bank dengan perangkat keras milik bank atau perangkat keras milik nasabah dan calon nasabah. Verifikasi tanpa tatap muka dilakukan menggunakan perangkat lunak milik bank dengan perangkat keras milik bank atau perangkat keras milik nasabah atau calon nasabah.

Layanan perbankan digital oleh bank berdasarkan perjanjian kemitraan antara bank dengan mitra bank berupa layanan informatif, layanan transaksional dan/atau layanan lain berdasarkan persetujuan OJK. Layanan informatif yang diselenggarakan oleh mitra bank wajib berupa LJK dan layanan transaksional diselenggarakan oleh mitra bank yang berupa LJK dan non-LJK (Susanto, 2014).

Bank memiliki kewajiban dalam melakukan penyelenggaraan layanan perbankan digital berdasarkan perjanjian kemitraan, yaitu: 1).Bank wajib memiliki kebijakan dan prosedur dalam penentuan mitra bank; dan 2).Perjanjian kerja sama secara tertulis dengan mitra bank yang disusun dengan menggunakan Bahasa Indonesia (Witasari, \& Setiono, 2015).
Dari penjelasan diatas dapat dikatakan inovasi pelayanan dengan meningkatkan teknologi informasi mengarhakan bank dalam suatu era baru yaitu perbankan digital. Layanan perbankan digital dapat diwujudkan sejak hubungan usaha antara nasabah dan bank dimulai sampai dengan berakhir, seperti proses pembukaan rekening hingga penutupan rekening dengan memamfaatkan teknologi informasi (Hamin, 2017). Namun, berkembangnya layanan perbankan digital juga meningkatkan resiko yang akan dihadapi oleh bank, untuk itu maka diterbitkanlah Peraturan OJK No.12/POJK.03/2018. Dengan adanya peraturan OJK ini, bank diharapkan dapat menyelenggarakan layanan perbankan digital dengan tetap mengedepankan manajemen risiko dalam penggunaan teknologi informasi.

\section{Perlindungan Nasabah Atas Penyelenggaraan Layanan Perbankan Digital}

Perlindungan nasabah atas penyelenggaraan layanan perbankan digital dapat dilakukan dengan mencegah atau menanggulangi keadaan yang tidak diharapkan nantinya oleh nasabah melalui peraturan perundang-undangan, perlindungan ini dikenal dengan perlindungan preventif (Candrawati, 2014). Kemudian terdapat perlindungan terhadap nasabah atas keadaan yang tidak diinginkan diatas yang telah terjadi serta merugikan nasabah, sehingga perlu adanya upaya dalam menyelesaikan permasalahan tersebut. Perlindungan yang tujuannya menyelesaikan masalah atau sengketa yang timbul dikenal dengan perlindungan represif (Jahri, 2016) 


\section{a. Perlindungan Preventif Terhadap Pengguna Nasabah Layanan Perbankan Digital}

Perlindungan nasabah yang sifatnya preventif secara umum dapat ditemukan dalam UndangUndang No.10 Tahun 1998 Tentang Perbankan, Undang-Undang No.8 Tahun 1999 Tentang Perlindungan Konsumen, Peraturan OJK No.12/POJK.03/2018 Tentang Penyelenggaraan Layanan Perbankan Digital Oleh Bank Umum

Perlindungan hukum yang diberikan oleh bank atas layanan perbankan digital jika dilihat berdasarkan UU Perbankan terdiri atas: a).Penyediaan informasi mengenai kemungkinan timbulnya resiko kerugian nasabah terkait layanan perbankan digital, yang dimaksudkan agar akses untuk memperoleh informasi perihal kegiatan usaha dan kondisi bank menjadi lebih terbuka yang sekaligus menjamin adanya transparansi dalam dunia perbankan; b).Rahasia bank, yang dimaksudkan agar kepercayaan masyarakat lahir apabila dari bank ada jaminan bahwa pengetahuan bank tentang data pribadi pengguna layanan perbankan digital ataupun data simpanan serta keadaan keuangan nasabah tidak disalahgunakan; dan c).Setiap bank wajib menjamin dana nasabah pengguna layanan perbankan digital yang disimpan di bank melalui dibentuknya Lembaga Penjamin Simpanan (Rani, 2017).

Selain itu, usaha pemerintah untuk melindungi nasabah perbankan secara umum juga dapat ditemukan dalam UU Perlindungan konsumen. Bank bertanggung jawab untuk melaksanakan amanat UU
Perlindungan Konsumen, dalam penyelenggaraan perlindungan nasabah pengguna layanan perbankan digital, bank bertanggung jawab untuk melaksanakan kewajiban-kewajiban sebagai pelaku usaha, diantaranya: a).Menerapkan itikad baik saat menjalankan kegiatan usaha, termasuk layanan perbankan digital; b).Memberikan pelayanan kepada nasabah dengan benar, jujur dan tidak diskriminatif; c).Memberikan jaminan kualitas barang maupun jasa yang dipasarkan kemasyarakat atas ketentuan standar kualitas barang maupun jasa, termasuk layanan perbankan digital; d).Informasi mengenai kondisi jaminan barang maupun jasa wajib diberikan oleh bank secara benar, jelas dan jujur. Bank selaku pelaku usaha wajib memberikan penjelasan penggunan, perbaikan dan pemeliharaan; e).Dalam hal menguji atau mencoba barang maupun jasa bank diwajibakan memberikan kesempatan serta memberikan garansi terhadap barang maupun jasa yang dipasarkan; dan f).Bank wajib memberi konpensasi, ganti rugi maupun penggantian atas kerugian akibat penggunaan dan pemamfaatan atas barang maupun jasa sesuai dengan perjanjian.

Selain pasal 29 ayat (4) mengenai penyediaan informasi mengenai kemungkinan timbulnya kerugian, pasal 40 ayat (1) dan ayat (2) menegenai rahasia bank, pasal 37B ayat (1) dan (2) mengenai jaminan atas simpanan nasabah melalui LPS dalam UU Perbankan dan pasal 18 tentang klausula baku dalam UU Perlindungan Konsumen, Peraturan OJK tentang Penyelenggaraan Layanan Perbankan Digital Oleh Bank Umum mengatur juga tentang 
Jurnal Pembangunan Hukum Indonesia

Volume 1, Nomor 3, Tahun 2019
Program Studi Magister IImu Hukum Fakultas Hukum Universitas Diponegoro perlindungan nasabah, dimana Peraturan OJK ini menyebutkan, bank penyelenggara layanan perbankan digital wajib menerapkan prinsip perlindungan konsumen sebagaimana dimaksud dalam ketentuan peraturan perundang-undangan mengenai perlindungan konsumen sektor jasa keuangan dan bank penyelenggara layanan perbankan digital wajib memiliki fungsi dan mekanisme penanganan setiap pertanyaan dan/atau pengaduan dari nasabah yang beroperasi selama 24 jam dalam sehari. Prinsip perlindungan nasabah mencakup transparansi, perlakuan yang adil, keandalan, kerahasiaan serta keamanan data/informasi nasabah dan penanganan pengaduan serta penyelesaian sengketa nasabah secara sederhana, cepat dan biaya terjangkau (Wonok, 2013).

\section{b. Perlindungan Represif Terhadap Nasabah Pengguna Layanan Perbankan Digital.}

Penyelesaian pengaduan nasabah merupakan salah satu bentuk perlindungan nasabah dalam rangka menjamin hak-hak nasabah (Panjaitan, 2012). Pengaduan nasabah yang tidak segera ditindaklanjuti berpotensi meningkatkan risiko reputasi bagi bank dalam jangka panjang sehingga dapat menurunkan kepercayaan masyarakat (Astrini, 2015).

Peraturan BI No.10/10/PBI/2008 Tentang Perubahan Atas Peraturan BI No.7/7/PBI/2005 Tentang Penyelesaian Pengaduan Nasabah menyebutkan "pengaduan adalah ungkapan ketidakpuasan nasabah yang disebabkan oleh adanya potensi kerugian finansial pada nasabah yang diduga karena kesalahan atau kelalaian bank". Peraturan $\mathrm{BI}$ No.10/10/PBI/2008 ini juga menyebutkan bank wajib menyelesaikan setiap pengaduan yang diajukan nasabah atau perwakilan nasabah melalui prosedur tertulis yang meliputi penerimaan pengaduan; penanganan dan penyelesaian pengaduan; serta pemantauan penanganan dan penyelesaian pengaduan.

Hasil wawancara dengan Ibu Daramarisa Dwi Permata, CS Kantor BRI Unit Pasar Boyolali, menyampaikan terkait pengaduan nasabah pengguna layanan perbankan digital akan ditindaklanjuti sesuai prosedur yang berlaku yang dimiliki oleh BRI. Dalam hal penerimaan pengaduan, CS BRI diwajibkan menerima setiap pengaduan yang diajukan oleh nasabah dengan ketentuan melengkapi fotocopi identitas dan dokumen pendukung lainnya. Umumnya setiap pengaduan yang diterima oleh CS BRI disamapaikan langsung oleh nasabah yang memiliki kendala atas layanan perbankan digital. Setelah menerima pengaduan dari nasabah, Ibu Daramarisa Dwi Permata menambahkan, bahwa CS BRI yang diharuskan memberikan penjelasan kepada nasabah mengenai prosedur penyelesaian pengaduan pada saat nasabah mengajukan pengaduan dan memproses pengaduan tersebut untuk dapat diselesaikan dihari itu juga. Apabila penyelesain pengaduan membutuhkan waktu yang lebih lama, maka CS BRI wajib memberikan bukti tanda terima pengaduan nasabah secara tertulis. 
Jurnal Pembangunan Hukum Indonesia

Volume 1, Nomor 3, Tahun 2019
Program Studi Magister Ilmu Hukum Fakultas Hukum Universitas Diponegoro
Dari hasil wawancara di atas, terlihat pihak BRI Kantor Unit Pasar Boyolali dalam menyelesaikan pengaduan nasabah atas layanan perbankan digital telah sesuai dengan ketentuan yang berlaku, yaitu ketentuan khusus penyelesaian pengaduan nasabah yang terdapat di dalam Peraturan $\mathrm{Bl}$ No.10/10/PBI/2008. Selain ketentuan penerimaan pengaduan, Peraturan BI No.10/10/PBI/2008 juga menyebutkan penanganan dan penyelesaian pengaduan nasabah wajib diselelesaikan oleh bank paling lambat 20 hari kerja setelah tanggal penerimaan pengaduan. Bank dapat memperpanjang jangka waktu penyelesaian pengaduan apabila terdapat kondisi tertentu.

Pengaturan penyelesaian pengaduan nasabah juga diatur dalam Surat Edaran OJK No.2/SEOJK.07/2014 Tentang Pelayanan dan Penyelesaian Pengaduan Konsumen Pada Pelaku Usaha Jasa Keuangan. Di dalam peraturan ini menyebutkan, bahwa bank dalam menyelesaikan pengaduan wajib disertai dengan pernyataan maaf serta menawarkan ganti rugi (Redress/Remedy) apabila nasabah tersebut mengalami kerugian materiil.

Dari hasil wawancara dengan Ibu Daramarisa Dwi Permata, CS Kantor BRI Unit Pasar Boyolali. Terdapat kesinambungan antara aturan yang ada di dalam Surat Edaran OJK No.2/SEOJK.07/2014 dengan praktik yang dilakukan di Kantor BRI Unit Pasar Boyolali. Ibu Daramarisa Dwi Permata menyampaikan, bahwasanya dalam melakukan penerimaan pengaduan nasabah, pihak CS BRI akan selalu melakakukan prosedur standar layanan dimana salah satunya adalah mengucapkan permintaan maaf kepada nasabah atas ketidakpuasan nasabah yang disebabkan adanya petensi kerugian ataupun kerugian finansial atas layanan perbankan digital yang dimiliki BRI. Selain permintaan maaf, pihak BRI akan melakukan ganti kerugian terhadap nasabah yang mengalami kerugian materiil atas penggunaan layanan perbankan digital milik BRI sesuai prosedur yang ada.

Ibu Daramarisa Dwi Permata, CS Kantor BRI Unit Pasar Boyolali juga menambahkan terkait prosedur pelayanan dan penyelesaian pengaduan yang dimiliki BRI harus lebih efisien dan efektif. Sebagai contoh, selain tatap muka langsung, CS BRI dalam penerimaan pengaduan nasabah terkait layanan perbankan digital dapat dilakukan melalui email ataupun surat sehingga memudahkan nasabah. Selain kemudahan di atas, CS BRI dalam berkomunikasi dengan nasabah wajib menggunakan format yang mudah dimengerti oleh nasabah sehingga terjalin komunikasi yang baik antara nasabah dengan pihak BRI.

Surat Edaran OJK No.2/SEOJK.07/2014 juga menyebutkan, prosedur pelayanan dan penyelesaian pengaduan nasabah yang diberikan oleh bank penyedia layanan perbankan digital wajib merahasiakan informasi nasabah kecuali kepada OJK atau atas persetujuan nasabah itu sendiri. Di dalam SE OJK ini juga bank diwajibkan untuk: 1).Memberikan perlakuan yang seimbang dan 
Jurnal Pembangunan Hukum Indonesia

Volume 1, Nomor 3, Tahun 2019
Program Studi Magister Ilmu Hukum Fakultas Hukum Universitas Diponegoro objektif kepada setiap pengaduan; 2).Memberikan kesempatan yang memadai kepada konsumen untuk menjelaskan materi pengaduan; 3).Memberikan kesempatan kepada pihak lain yang mempunyai kepentingan terhadap pengaduan, untu memberikan penjelasan dalam penyelesaian pengaduan (jika ada); dan 4).Bank wajib mengadministrasikan pelayanan dan penyelesaian pengaduan yang meliputi identitas nasabah, materi pengaduan dan tindakan yang telah dilakukan unruk menyelesaiakan pengaduan.

Menyangkut upaya perlindungan nasabah pengguna layanan perbankan digital yang dilakukan oleh bank sebagai penyedia layanan sebenarnya merupakan bentuk pertanggungjawaban pihak bank kepada nasabah yang mengalami kerugian (Talumewo, 2013). Pertanggungjawaban ini dimaksudkan untuk melindungi hak nasabah sesuai amanat UU Perbankan, UU Perlindungan Konsumen dan Peraturan OJK No.12/POJK.03/2018. Pertanggungjawaban ini juga dimaksudkan untuk mengurangi potensi risiko turunya reputasi bagi bank dalam jangka panjang sehingga tidak menurunkan kepercayaan masyarakat terhadap bank penyedia layanan perbankan digital.

\section{SIMPULAN}

Layanan perbankan digital adalah layanan perbankan elektronik yang dikembangkan dengan mengoptimalkan pemamfaatan data nasabah dalam rangka melayani nasabah secara lebih cepat, mudah dan sesuai dengan kebutuhan (customer experience) serta dapat dilakukan secara mandiri sepenuhnya oleh nasabah, dengan memperhatikan aspek pengamanan. Layanan perbankan digital merupakan inovasi dari perbankan untuk memenuhi kebutuhan nasabah yang berkembang saat ini dengan memamfaatkan Teknologi Informasi. Di Indonesia penyelenggaran layanan perbankan digital yang disediakan oleh bank diatur di dalam Peraturan OJK No.12/POJK.03/2018 Tentang Penyelenggaraan Layanan Perbankan Digital Oleh Bank Umum.

Terdapat dua jenis perlindungan nasabah pengguna layanan perbankan digital, yaitu perlindungan preventif dan perlindungan represif. Perlindungan preventif merupakan upaya yang dilakukan oleh pemerintah dalam melindungi konsumen atau nasabah pada umumnya. Upaya tersebut adalah dengan diundangkannya UU Perbankan dan UU Perlindungan Konsumen, selain itu juga perlindungan nasabah pengguna layanan perbankan digital dapat ditemukan dalam Peraturan OJK Tentang Penyelenggaraan Layanan Perbankan Digital Oleh Bank Umum. Bukan hanya perlindungan preventif, terdapat juga upaya perlindungan represif yaitu upaya yang dilakukan apabila terjadi suatu permasalahan yang berpotensi merugikan nasabah. Salah satu upaya tersebut adalah pertanggungjwaban pihak penyedia layanan perbankan digital yaitu bank itu sendiri. Pertanggungjawaban pihak bank tersebut dapat berupa penanganan pengaduan nasabah hingga penggantian kerugian terhadap nasabah. 
Jurnal Pembangunan Hukum Indonesia

Volume 1, Nomor 3, Tahun 2019
Program Studi Magister Ilmu Hukum Fakultas Hukum Universitas Diponegoro

\section{DAFTAR PUSTAKA}

\section{BUKU}

Ikatan Bankir Indonesia. (2014). Mengelola kualitas

Layanan Perbankan. Jakarta: PT. Gramedia Pustaka Utama.

Salim, H.S, \& Nurbani, Erlies S. (2014). Penerapan

Teori Hukum Pada Penelitian Tesis dan

Disertasi. Jakarta: PT. Raja Grafindo Persada.

Sutedi, A. (2014). Aspek Hukum Otoritas Jasa

Keuangan. Jakarta: Raih Asa Sukses.

\section{JURNAL \& PROSIDING}

Astrini, Dwi A. (2015). Perlindungan Hukum

Terhadap Nasabah Bank Pengguna Internet

Banking dari Ancaman Cybercrime. Lex

Privatum, Vol. 3, (No.1), pp 149-160.

Candrawati, Ni Nyoman A. (2014). Perlindungan

Hukum Terhadap Pemegang Kartu E-Money

Sebagai Alat Pembayaran Dalam Transaksi

Komersial. Jurnal Magister Hukum Udayana

(Udayana Master Law J ournal), Vol. 3, (No.1), pp 1-16.

Chosyali, Achmad., \& Sartono, Tulus. (2019).

Optimalisasi Peningkatan Kualitas Kredit

Dalam Rangka Mengatasi Kredit Bermasalah.

J urnal Law R eform, Vol.15, (No.1), pp. 98-112.

Cvijovic, Jelena., Stankovic, Milica Kostic., \& Relljic,

Marija. (2017). Customer Relationship

Management In Banking Industry: Modern Approach. Industrija J ournal, Vol. 45, (No.3), pp. 151-165.
Dendhana, Toto O. (2013). Penerapan Prudential Banking Principle dalam Upaya Perlindungan Hukum Bagi Nasabah Penyimpan Dana. Lex et Societatis, Vol. 1, (No. 1), pp. 40-53.

Hamin, Mohammad W. (2017). Perlindungan Hukum Bagi Nasabah (Debitur) Bank Sebagai konsumen Pengguna Jasa Bank Terhadap Resiko dalam Perjanjian kredit Bank. Lex Crimen, Vol. 6, (No. 1), pp 46-53.

Jahri, A. (2016). Perlindungan Nasabah Debitur Terhadap Perjanjian Baku Yang Mengandung Klausula Eksonerasi Pada Bank Umum Di Bandar Lampung. Fiat J ustisia J ournal of Law, Vol. 10, (No.2), pp. 125-148.

Kholis, N. (2018). Perbankan Dalam Era Baru Digital. J urnal Economicus, Vol.9, (No.1), pp.80-88.

Marlina, Asti., \& Bimo, Widi Aryo. (2018). Digitalisasasi Bank Terhadap Peningkatan Pelayanan Dan Kepuasan Nasabah Bank . J urnal IImiah Inovator, Edisi Maret, pp. 14-34.

Mbama., \& Catejan. (2018). Digital banking, customer experience and bank financial performance : UK customers' perceptions. International Journal of Bank Marketing, Vol.36, (No.2), pp. 230-255 .

Palilati, Rati M. (2016). Perlindungan Hukum Konsumen Perbankan oleh Otoritas Jasa keuangan. Jurnal IUS, Vol. 4, (no. 3). pp 5067.

Panjaitan, Leo. T. (2012). Analisis Penanganan Carding dan Perlindungan Nasabah dalam kaitannya dengan Undang-Undang Informasi 
Jurnal Pembangunan Hukum Indonesia

Volume 1, Nomor 3, Tahun 2019
Program Studi Magister Ilmu Hukum Fakultas Hukum Universitas Diponegoro

dan Transaksi Elektronik No. 11 Tahun 2008. SUMBER ONLINE

Incomtech Jurnal Telekomunikasi dan Otoritas Jasa Keuangan. (2019). Panduan komputer, Vol. 3, (No. 1), pp. 1-25.

Rani, M. (2017). Perlindungan Otoritas Jasa keuangan Terhadap kerahasiaan dan keamanan data pribadi Nasabah Bank. J urnal Selat, Vol. 2, (No.1), pp 168-181.

Susanto, C. (2014). Tinjauan Hukum tentang Pengawasan Bank dan Perlindungan Nasabah oleh Otoritas Jasa keuangan. Jurnal IImu Hukum Legal opinion, Vol. 2, (No. 5), pp 1-8.

Talumewo, F. (2013). Pertanggungjawaban Bank Terhadap Nasabah Yang Menjadi Korban Kejahatan Informasi Dan Transaksi Elektronik (ITE). J urnal Lex Crime, Vol.II, (No.1), pp. 132147.

Vebiana, V. (2018). Perbankan Digital, Pengalaman Pelanggan, dan Kinerja Keuangan Bank Syariah. Prosiding IRONS (Industrial Research Workshop and National Seminar), Vol.9, pp. 747-751.

Witasari, Aryani, \& Setiono, Aris. (2015). Perlindungan Hukum Pengguna Jasa Electronic Banking (e-Banking) ditinjau dari Perspektif Hukum Pidana Indonesia. Jurnal Pembaharuan Hukum, Vol. 2, (No. 1), pp 126137.

Wonok, David. Y. (2013). Perlindungan Hukum Atas Hak - Hak Nasabah Sebagai konsumen Pengguna Jasa Bank Terhadap Risiko yang Timbul dalam Penyimpanan Dana. Jurnal Hukum Unsrat, Vol. 1, (No. 2), pp. 59-71. 